\title{
Reading in A Digital Age: e-Books Are Students Ready For This Learning Object?
}

\author{
Nicole Buzzetto-More \\ University of \\ Maryland Eastern \\ Shore, USA
} \author{
more@umes.edu
}

\author{
Retta Sweat-Guy \\ Fayetteville State \\ University, USA
}

\author{
rquy@uncfsu.edu
}

\author{
Muna Elobaid \\ University of \\ Maryland Eastern \\ Shore, USA
}

meelobaid@umes.edu

\begin{abstract}
E-Books are a type of e-content based learning object whose benefits may include: hyper linking, nonlinearity, data density, customizability, greater distribution, low costs, search ability, and other multimedia features (Shiratuddin, Hassan, \& Landoni, 2003). Originally introduced in the late 1990's, the growth of e-books has been sluggish. Midgley reported (as cited in Wilson, 2003) that while proponents believe that e-books will come to change the way we understand reading and represent the future of reading in this digital age, critics explain that reading on a screen is an unpleasant experience that has, and will continue to, stymie the growth of e-books (Weeks, 2002). Concurrently, Prensky (2001) reports that the new generation of students entering higher education, the "Millennials", are fascinated by new technologies and considers it as a natural part of their environment. This paper represents the findings of students' reported experiences and perceptions of e-books at a historically Black university.
\end{abstract}

Keywords: e-books, learning objects, handheld computing.

\section{Literature Review}

Learning objects were defined by Cohen and $\mathrm{Nycz}$ (2006) as knowledge-based objects that are self-contained and reusable. Gallenson, Heins, and Heins (2002) refer to learning objects as units of instructional content that facilitate content mastery and link to learning outcomes; and de Salas and Ellis (2006) explain that learning objects frequently include a variety of multimedia learning materials. Their usage has been shown to enhance the teaching and learning process (Recker et al., 2005. Recker et al. describe teaching as a design based profession where educators see to use resources digital and otherwise to enhance the learning experiences of students and explain that learning objects because of their customizability can become "catalysts for the creation of locally

Material published as part of this journal, either on-line or in print, is copyrighted by the Informing Science Institute. Permission to make digital or paper copy of part or all of these works for personal or classroom use is granted without fee provided that the copies are not made or distributed for profit or commercial advantage AND that copies 1) bear this notice in full and 2) give the full citation on the first page. It is permissible to abstract these works so long as credit is given. To copy in all other cases or to republish or to post on a server or to redistribute to lists requires specific permission and payment of a fee. Contact Publisher@InformingScience.org to request redistribution permission. relevant solutions to support learning" (p. 198).

Most learning objects discussed today are comprised of electronic content or econtent that has been defined by Shiratuddin, Hassan, and Landoni (2003) as information that is made available in digital formats and is viewed on a screen rather than on paper. E-Books are just one example of an e-content based 
learning object whose benefits include: hyper linking, nonlinearity, data density, search ability, enhanced presentation, and multimedia features (Shiratuddin, Hassan, \& Landoni, 2003).

There are many definitions of e-books. Mattison (2002) defined an e-book as a monograph akin to a printed book that is made available in a digital format to be read online or downloaded to a handheld device. Abbott and Kelly (2004) explained that while an e-book can be as simple as a scanned version of a printed publication, inherent in e-books is the ability to make available a number of features to the reader which include multimedia, hyperlinks and other interactive components, search features, and customizability to change text size or convert text to audio so as to meet the needs of special readers. As a result, they explained that print on demand books should not be considered e-books, as once printed, many of the qualities inherent in the electronic format cease to be available.

What was originally introduced in the late 90's as digital reproductions of hardcopy text have become flexible mixed content resources that can be aggregated and disaggregated into databases (Wicht, 2006). Having grown much slower than originally predicted, they are available in several formats through a variety of pricing structures including subscriptions, rental fees, pay per page, and even as free e-books. In many cases, digital encryption is utilized to ensure that no infringement on copyright occurs.

Downes (2007) explains that e-books can have a relatively long lifespan as they may be useful for decades or even centuries. This may lead to an e-book having outrun the lifespan of a traditional print volume, which is no longer printed after it ceases to generate revenue.

The e-book discussion has been mixed and primarily focused in library and literary communities. Midgley reports (as cited in Wilson, 2003) that while some authors have proclaimed that e-books represent the future of reading, others have explained that reading on a screen is an unpleasant experience that has, and will continue to, stymie the growth of e-books (Weeks, 2002). At the same time, the newest generation of readers has been exposed to e-books often before they can read or even walk through popular children's toys and through read along features on children's DVDs and video games (Johnson \& Harroff, 2006). Realizing the benefits to children, organizations such as the Children's Digital Library are encouraging the creation and distribution of ebooks to children across the globe (Johnson \& Harroff, 2006).

The findings of a 2004 study conducted by the National Endowment for the Arts entitled "Reading at Risk: A Survey of Literary Reading in America" reported that less than half of Americans over the age of 18 read books, novels, short stories, or plays. Similarly, a new study conducted by the National Survey of America's College Students found that half of four-year college students and $75 \%$ of two-year college students are lacking crucial literacy skills. Additionally, Charlotte Johnson and William Harroff (2006) stated:

E-books are more likely to be a part of the solution rather than a symptom of the illiteracy problem. Rather than focusing solely of digitizing print text and worrying about redefining the term book, publishers of electronic materials should take full advantage of the multimodal leaning styles that can be addressed by welldesigned electronic publications. (pg. 10)

At the International Digital Publishing Forum in 2006 (as cited in Rogers, 2006), William Endhoven of iRex Technologies said that despite the high number of hours individuals spend in front of computer screens, people still do not want to read at length on their computer. He explained that when faced with more than three or four pages most people would choose to print. As a result, he suggested that e-books need to develop their own identities. Also in attendance, Martin Gorner of Mobipocket predicted that in five years e-books will be delivered by smart phones which will make Blackberrys and PDAs obsolete. Elizabeth Mackey of eReader (as cited in Rogers, 2006) 
agreed that smart phones may mark the future of e-books and added that currently a lack of quality exists and that in the future we should see not just entire books put also smaller texts which she referred to as "information snacks". Mackey also added that electronic devices should come with free e-books to promote reading.

Possibly further enforcing the future of smart phones, the 2006 Horizon Report published by the New Media Consortium and EDUCAUSE (as cited in Johnson \& Harroff, 2006), explained that social computing, personal broadcasting, multipurpose cell phones or smart phones, educational gaming, augmented reality, context aware devises, and open access will have a major impact on education within the next five years.

E-books on handheld devices have already become commonplace within the medical community where they serve as invaluable references to practitioners (Fox, 2003) and while handheld devices make e-books highly portable, issues of screen size, battery life, readability, slow page turning, and compatibility between devices has persisted (Abbott \& Kelly, 2004).

A survey conducted by the electronic publisher Versaware (as cited in Rogers, 2001) claimed that $87 \%$ of the students polled favored e-books of traditional print volumes. In contrast, a number of studies have shown that the majority of college students are not accepting of e-books (Mash, 2003; Rogers \& Roncevic, 2002).

Seeing a promising return on their investment, Harlequin, publisher of romance novels, introduced an e-book line in October 2005 and received such an overwhelming response they are now introducing $40 \%$ of their front list as e-books and also launching a series of minis which can be downloaded for 99 cents (Rogers, 2006).

A question has persisted as to whether e-book distribution in academia should be a profit-making venture. Berglund, Morrison, Wilson, and Wyne (2004) defined free e-books as involving "no direct costs to acquire, access, read, copy, or use." After examining free e-books in the humanities they concluded that there were a large number of free e-books for higher education usage, available in a number of formats, but often found to have varying quality. Google Books has joined the e-book forum by linking the public to an ever growing archive of books allowing readers to browse available pages, read online reviews, find out where they can buy books or borrow them a nearby library, and in many cases makes full text available for online reading. Their listing includes academic books, popular titles and old, out-of-print and public domain volumes. A handful of publishing companies have also joined the mix such as the non-profit publisher the Informing Science Press, which sells hardcopy texts but make digital copies of all of their books and journals available in digital form for free.

The largest vendors of e-books are NetLibrary, EBSCO, Ebrary, Knovel, Safari, Books 24 x 7, and Gale (Wicht, 2006). Another source for e-book access is digital learning object repositories such as Merlot (Multimedia Educational Resources for Learning and Online Teaching), Teach IS, Informing Science Learning Object Repository, California Virtual Campus Object Library, PENDOR (Pennsylvania Education Network Digital Object Repository), Wisc-Online, EdNA, and Careo which all serve to promote and distribute the sharing of learning objects among educators.

Concerned with functionality the Open e-Book Forum which has been renamed the International Digital Publications Forum is working on standards that will ensure interoperability for e-books (Johnson \& Haroff, 2006).

Downes (2007) explains that open publication enables the widest possible audience, means of dissemination, and visibility for an intellectually work that studies have proven to be more frequently cited than their print counterparts. He explains that although open is often synonymous with free, low cost or "affordable" distribution may be the most effective in encouraging sustainability and persistence. 
A study of e-book usage at Bond University in Australia concluded that despite a variety of issues reported by students the benefits indicate "e-books can bring added dimensions to the leaning environment when used in an appropriate context".

A study conducted in the UK using EBONI's e-book evaluation methodology evaluating e-books on five different portable devices found that after participating in the study and using e-books half of the participants would continue their usage with the other half explaining that they would not. Reasons for continued usage included portability, hypertext, and searchability while reasons for disuse included price, battery life, lack of functionality, weight and limited advantages of printed text (Wilson, 2003). Also using the EBONI methodology and examining e-books on handheld devices, the study conducted by Dearnley and McNight at Loughborough University (as cited in Wilson, 2003) found that glare and screen quality were a problem; another at the University of Virginia conducted by Marshall and Ruotolo (as cited in Wilson, 2003) reported that the highlighting and underlying features were useful to students who used e-books in academic classes; and studies at Rochester Institute of Technology (Electronic Books in Libraries Project, 2002) and two Illinois colleges (Peters, 2000) found that poor battery life and the inability to locate a correct place quickly were significant issues.

Research has shown that reading from screen is $20 \%$ to $30 \%$ slower than reading from paper (Alshaali \& Varshney, 2005; Dillon, 1992). As a result, AlShaali and Varshney (2005) concluded that text displayed on a computer screen should contain at least $25 \%$ less text than paper media. They further noted reasons for reducing the amount of text when reading from handheld devices, citing smaller screens resulting in greater effort to move from one screen to the next.

While Moore and Zabrucky (1995) who compared young and older adults' reading performance under self-paced conditions from texts presented by a computer and on a printed page found better reading comprehension from both groups from a computer; Poon and Meyer (1997) who also conducted a study based on age where adults read in print, on self-paced computer screens, or on computer screens paced by machine found that older adults' comprehension was most efficient with print, younger subjects' with computers. Further, they found that when asked if they liked reading from computer screens, $67 \%$ of younger and $46 \%$ of older subjects said yes.

Dyson and Haselgrove (2005) examined reading patterns and scrolling movements and found that the overall time spent pausing between movements was the best predictor of comprehension. As a result, De Salas and Ellis (2006) recommend that they be organized strategically into topically meaningful information 'chunks'.

Ted Striphas (2006) of Indiana University discussed issues of ownership, copyright, control, and consumerism in relation to e-books referring to Sven Birket's 1994 publication The Guttenberg Elegies: The Fate of Reading in an Electronic Age, he claims that the "ecology of reading" may change as electronic formats diminish our abilities to engage in "deep reading" and as communication technologies continue to change our "values and sensibilities".

Historically Black colleges and universities have traditionally lagged behind majority institutions in the incorporation of e-learning into their curriculum (Buzzetto-More \& Sweat-Guy, 2006). Further a recent study showed that while the technology access and ownership of students at minority serving institutions is comparable to what has been reported out of traditionally White institutions, the students come to college are less prepared to use the internet and libraries for scholarly pursuits (Buzzetto-More \& Sweat-Guy, 2006).

This study provides research on a population that has previously not received sufficient focus. Whereas a number of studies have been conducted either at majority higher education institutions, this is the first study of this size and magnitude being conducted at Historically Black College and/or University (HBCU) focusing on a population that is traditionally missing from the litera- 
ture as the critical mass of African American college students can be found at HBCUs (Brown, 2004). It is important to note that HBCUs confer a statistically significant percentage of the bachelor's degrees earned by African Americans whereas four-year public and private colleges and universities graduate one-fourth of the total number of bachelor's degrees awarded in the U.S. to African Americans. Additionally, while the number of African Americans at both HBCUs and majority institutions continues to grow, African American students are not completing their degrees at majority institutions at the same rate as those attending HBCUs (Brown, 2004).

\section{Methodology}

Founded in 1886, the University of Maryland Eastern Shore (UMES) is a historically Black, 1890 land grant institution and a member of the University System of the State of Maryland. The student body is approximately 3,762, reporting a student population that is approximately $74 \%$ African-American and $26 \%$ White and other. Almost $11 \%$ of the student population is international students that primarily come from the continent of African and the Caribbean region. The majority of incoming freshmen have an SAT score of under 1,000, the retention rate is $69.7 \%$ and the graduation rate is $52.6 \%$. The Department of Business Management and Accounting, which is currently in under accreditation consideration with the AACSB, is one of the largest departments on campus with over 420 majors, offering programs that include Business Management, Marketing, Accounting, and Business Education.

The population included in this study was freshmen and sophomores enrolled in BUED 212: Computer Concepts during the Spring 2007 academic term. The instrument utilized contained a mixture of Likert-Scale, multiple-choice, and yes/no questions. SPSS was utilized during the data analysis process. Likert-Scale questions were evaluated based on mean, mode, minimum and maximum responses, standard deviation, and percentages. Multiple-choice and yes/no responses were evaluated on a percentage basis. Additionally, a one-way ANOVA and cross tabulations were run to compare means and to determine correlations between variables, respectively.

The survey included a range of questions that looked at students' technology ownership and access, online newsgathering and information acquisition habits, experiences with e-books, textbook purchasing habits, opinions of e-books, and comfort with regard to reading on a screen.

\section{Findings}

There were 261 students that responded to the survey. Of which $78.7 \%$ (203) were African American, 11.2\% (29) African, 4.3\% (11) White, 1.6\% (4) Hispanic, 1.6\% (4) Caribbean, and $.8 \%$ (2) Asian. The majority of the respondents were female, $60.2 \%$ (157) and nearly $74 \%$ between the ages of $17-19 ; 22.2 \% 20-25 ; 1.1 \% 26-30 ; 1.1 \% 31-35$, and less than .5\% 40-50. Thirty-seven percent of the respondents were majors from the Department of Business, Management, and Accounting which include business administration, management, accounting, marketing, business education, finance and human resources; $1.2 \%$ listed math \& computer science; $.4 \%$ engineering; and $61.4 \%$ other.

According to the findings, $86.9 \%$ of the respondents own computers, which is slightly lower than the $98 \%$ reported in a 2006 EduCause Study (Salaway, Katz, \& Caruso, 2006) and was slightly higher than a 2005 study conducted at two HBCUs (Buzzetto-More, Sweat-Guy, \& Jewell, 2006). With respect to their computer skills $5.5 \%$ rated themselves as virtually a novice computer user, $40.3 \%$ rated themselves as having some experience; $47.8 \%$ as intermediate; and $6.3 \%$ as expert users.

Almost all of the respondents $92.7 \%$ have internet access at their local residence which is slightly higher than the findings of a 2006 study conducted at two HBCU's that found an $86 \%$ rate of home internet access (Buzzetto-More \& Sweat-Guy, 2007). Participants in this study also noted 
their type of internet access with $69 \%$ having high speed internet access or some kind, $22 \%$ responding that they are not sure, and $9 \%$ using a modem. Most of the respondents $87.6 \%$ said they go online daily, which mirrored the findings of Buzzetto-More and Sweat-Guy.

Ninety-eight percent of the respondents reported that they feel comfortable reading off a computer screen this was higher than what was reported by Poon and Meyer in 1997 who reported that $67 \%$ of the young adults they studied liked reading from a computer screen.

Only $22 \%$ of the respondents reported that had read an e-book, concurrently $44 \%$ of the respondents said that they would opt to purchase an e-book over a traditional book. This means that the vast majority of respondents lacked e-book experience and that the majority of students prefer traditional paper-based text. Furthermore, the majority of respondents $(80 \%)$ said that they prefer to purchase their textbooks at the bookstore verses an online retailer. These findings differed from the findings of a survey conducted by the electronic publisher Versaware (as cited in Rogers, 2001) that claimed that $87 \%$ of the students polled favored e-books of traditional print volumes; however, it is similar to the findings of Mash (2003) as well as Rogers and Rocevic (2002) which found that the majority of college students are not accepting of e-books.

When asked to respond to the question "when I need to read a long passage that is on the computer, I usually print out a copy" the majority of participants $58.6 \%$ agreed with $21.5 \%$ expressing neutrality. Additionally, $54.8 \%$ said that they prefer hardcopy to a digital format with $31 \%$ expressing neutrality. Finally, only $25 \%$ of the participants agreed that purchasing an e-book is an excellent way to save money with $46 \%$ expressing neutrality.

\section{Table 1: Responses to Scaled Questions}

\begin{tabular}{|l|c|c|c|c|c|c|c|c|} 
& $\mathrm{SA}$ & $\mathrm{A}$ & $\mathrm{N} / \mathrm{U}$ & $\mathrm{D}$ & $\mathrm{SD}$ & Missing & Mean & Stdev \\
& 5 & 4 & 3 & 2 & 1 & & \\
I do NOT mind reading off & 47.9 & 33.7 & 10.7 & 5.0 & 1.1 & 1.5 & 4.24 & .921 \\
$\begin{array}{l}\text { a computer screen. } \\
\text { I do NOT like to read off a } \\
\text { computer screen. }\end{array}$ & 2.7 & 5.4 & 11.9 & 30.7 & 41.4 & 8.0 & 1.88 & 1.032 \\
$\begin{array}{l}\text { When I need to read a long } \\
\text { passage that is on the } \\
\text { computer, I usually print } \\
\text { out a copy. }\end{array}$ & 31.4 & 27.2 & 21.5 & 7.7 & 10.0 & 2.3 & 3.64 & 1.284 \\
$\begin{array}{l}\text { When reading, I prefer } \\
\text { hardcopy to a digital for- } \\
\text { mat. }\end{array}$ & 26.4 & 28.4 & 31.0 & 6.9 & 4.2 & 3.1 & 3.62 & 1.082 \\
$\begin{array}{l}\text { If I had the option, I would } \\
\text { purchase an e-book over a } \\
\text { traditional textbook. }\end{array}$ & 6.9 & 13.4 & 24.5 & 21.8 & 23.4 & 10.0 & 2.54 & 1.238 \\
$\begin{array}{l}\text { Purchasing an e-book is a } \\
\text { great way to save money. }\end{array}$ & 8.8 & 16.5 & 46.0 & 3.4 & 8.4 & 16.9 & 3.17 & 1.023 \\
\hline
\end{tabular}

The respondents were asked to rate several questions regarding e-books using a five point Likert scale where $5=$ strongly agree; $4=$ agree; $3=$ neutral/undecided; $2=$ disagree; and $1=$ strongly disagree. The results are presented in Table 1 along with the mean, standard deviation and the percentage of missing responses. 


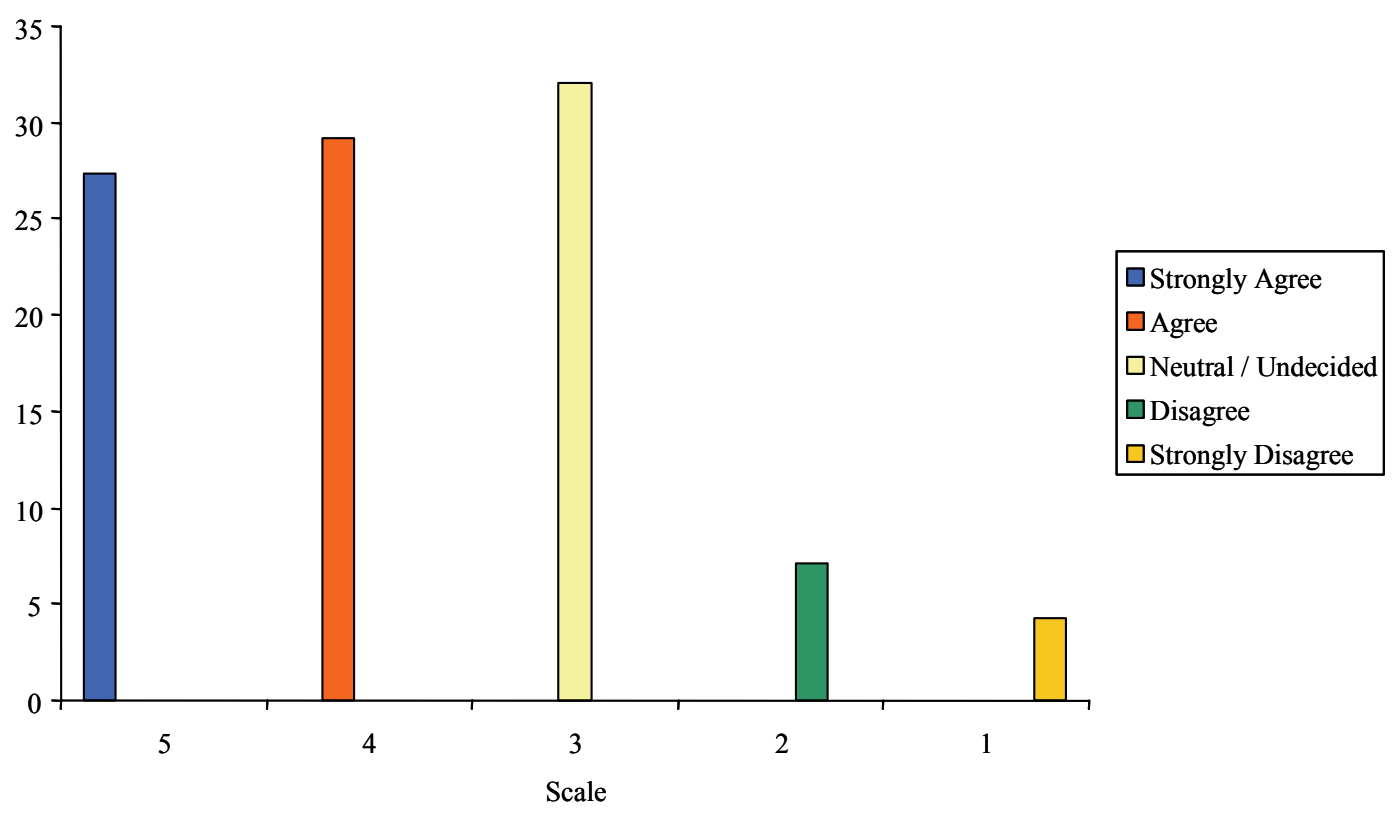

Figure 1: Students' Preference for Reading Hardcopy vs. Digital Format

Figure 1 represents the distribution of students' responses by percentage in respect to their preference for reading hardcopy versus a digital format using the 5-point Likert scale with 5=strongly agree and $1=$ strongly disagree. Over $27 \%$ reported strongly agree, $29.2 \%$ agree, $32.0 \%$ neutral/undecided, $7.1 \%$ disagree, and $4.3 \%$ strongly disagree.

Figure 2 illustrates student responses to the question "If I had the option, I would purchase an ebook over a traditional textbook" in accordance the response distribution using a 5-point Likert scale with $5=$ strongly agree and $1=$ strongly disagree. Over $7 \%$ strongly agree, $14.9 \%$ agree, $27.2 \%$ neutral/undecided, $24.3 \%$ disagree, and $26.0 \%$ strongly disagree.

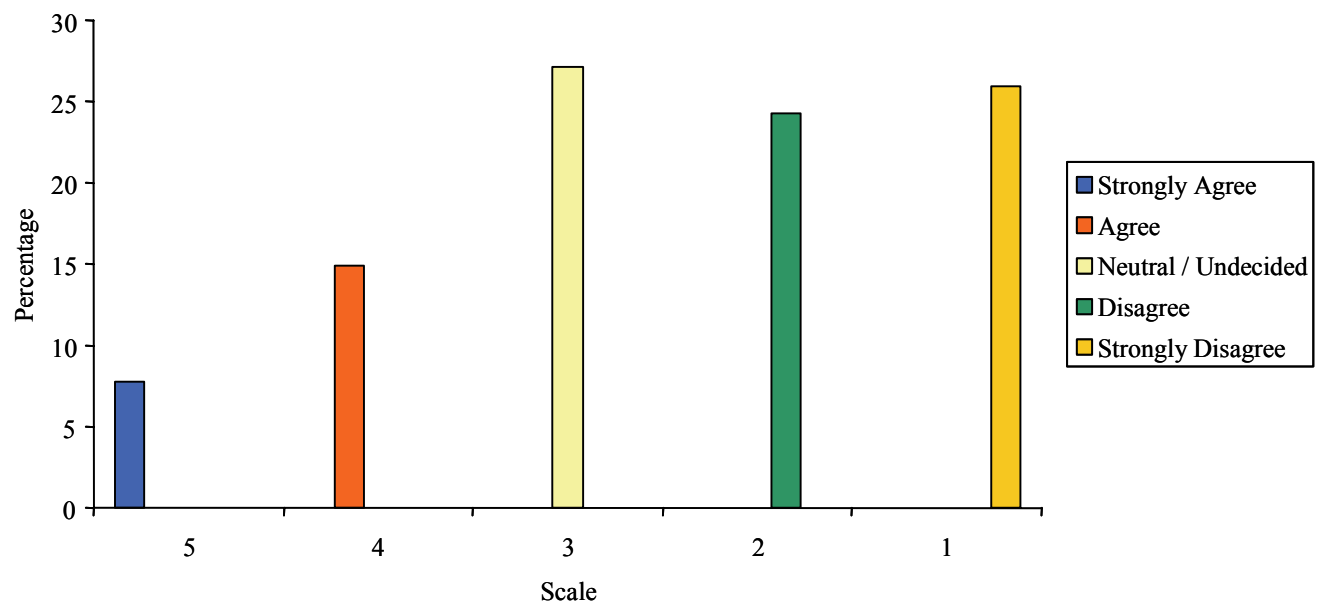

Figure 2: Students' Preference for Purchasing an e-Book vs. Traditional Textbook 
A cross tabulation was run to determine the joint distribution of the different age groups with respect to their responses to the question "I would opt to purchase an e-book over a traditional textbook" using a 5-point Likert scale with $5=$ strongly agree and $1=$ strongly disagree. The percentages are based on the age group, as presented in Table 2, with 50\% of the 17 year old population strongly disagreeing; the largest percentage of $18-19$ year olds were neutral $(30.6 \%)$; over $56 \%$ of the 20-21 age group equally disagreed or strongly disagreed; the majority of the 22-23 age group (77.8\%) either disagreed or strongly disagreed; the $24-25$ age group reported $33 \%$ for neutral, disagree, and strongly disagree; the 26-30 year olds were equally divided with $50 \%$ disagreeing and $50 \%$ strongly disagree; lastly, the $31-35$ age group were equally split with $33.3 \%$ strongly agreeing, neutral, and disagreeing.

\begin{tabular}{|c|c|c|c|c|c|c|c|}
\hline \multirow[t]{2}{*}{ Likert Scale } & \multicolumn{7}{|c|}{ Age } \\
\hline & 17 & $18-19$ & $20-21$ & $22-23$ & $24-25$ & $26-30$ & $31-35$ \\
\hline Strongly Agree & $0 \%$ & $6.4 \%$ & $10.3 \%$ & $11.1 \%$ & $0 \%$ & $0 \%$ & $33.3 \%$ \\
\hline Agree & $0 \%$ & $16.8 \%$ & $15.4 \%$ & $0 \%$ & $0 \%$ & $0 \%$ & 0 \\
\hline Neutral & $25 \%$ & $30.6 \%$ & $17.9 \%$ & $11.1 \%$ & $33.3 \%$ & $0 \%$ & $33.3 \%$ \\
\hline Disagree & $25 \%$ & $23.1 \%$ & $28.2 \%$ & $22.2 \%$ & $33.3 \%$ & $50 \%$ & $33.3 \%$ \\
\hline Strongly Disagree & $50 \%$ & $23.1 \%$ & $28.2 \%$ & $55.6 \%$ & $33.3 \%$ & $50 \%$ & $0 \%$ \\
\hline
\end{tabular}

Additionally, a one-way ANOVA was run to compare the means of students' preference for purchasing an e-book vs. traditional textbook with computer skills, students comfort level with reading on a screen, and with whether or not they had ever read an e-book. The results are expressed in Table 3.

\section{Table 3: A One-Way ANOVA Comparing Means for Students' Preference for Pur- chasing an e-Book vs. Traditional Textbooks}

\begin{tabular}{|l|c|c|c|c|c|}
\hline & $\begin{array}{c}\text { Sum of } \\
\text { Squares }\end{array}$ & df & $\begin{array}{c}\text { Mean } \\
\text { Square }\end{array}$ & F & Sig. \\
$\begin{array}{l}\text { Rank as a computer user \& I } \\
\text { would purchase an e-book }\end{array}$ & .811 & 1 & .811 & 1.677 & .197 \\
$\begin{array}{l}\text { I am comfortable reading } \\
\text { from a computer screen \& I } \\
\text { would purchase an e-book }\end{array}$ & .002 & 1 & .002 & .134 & .715 \\
$\begin{array}{l}\text { I have read an e-book \& I } \\
\text { would purchase an e-book }\end{array}$ & .846 & 1 & .846 & 4.952 & .027 \\
\hline
\end{tabular}

The one-way ANOVA revealed mean differences for students' preference for purchasing an ebook vs. traditional textbook and whether or not they had ever read an e-book as statistically sig- 
nificant, $\mathrm{p}<.05$ and $=.027$. However, when comparing the means of computer user skills and students' reported level of comfortable reading on a computer screen with their preference for purchasing an e-book, the results were not statistically significant, there was no significant difference between the means, $\mathrm{p}>.05$ and $=.197$ and .715 , respectively.

Students were also asked to rate the frequency of their online activities for gathering news/information not school related, readings newspapers or magazines, and visiting libraries/journals/databases for research which is depicted in Table 4. Fifty-one percent of the participants said that they use the internet to gather news and or information that is not school related daily or frequently; $32.2 \%$ said that they read newspapers or magazines online daily of frequently with $33.5 \%$ responding rarely or never; and only $24.2 \%$ said that they visit libraries or journals for research daily of frequently with $38.7 \%$ responding sometimes, $28.6 \%$ rarely, and $8.1 \%$ never.

\begin{tabular}{|l|c|c|c|c|c|}
\hline \multicolumn{5}{|c|}{ Table 4: Frequency of Online Activities } \\
\hline \multicolumn{1}{|c|}{ Online Activity } & Daily & Frequently & Sometimes & Rarely & Never \\
$\begin{array}{l}\text { Gathering news/ information } \\
\text { not school related }\end{array}$ & 22.2 & 29.0 & 30.2 & 14.7 & 4.0 \\
$\begin{array}{l}\text { Reading newspapers or maga- } \\
\text { zines }\end{array}$ & 15.5 & 16.7 & 34.3 & 26.7 & 6.8 \\
$\begin{array}{l}\text { Visiting libraries/journal/ data- } \\
\text { bases for research }\end{array}$ & 8.9 & 15.3 & 38.7 & 28.6 & 8.1 \\
\hline
\end{tabular}

\section{Limitations}

This study provides research on a population that has previously not received sufficient focus. Whereas a number of similar studies have been conducted at majority higher education institutions, this is the first study conducted at a Historically Black University. This paper builds on the findings of a number of studies by providing timely information on a targeted population. The most significant limitation of this study is that it focused solely on participants attending minority-serving institutions. It currently does not have data that has been acquired at a majority institution for comparison. Additionally, when conducting studies at HBCUs because of their low enrollment of non-blacks, as witnessed with the racial distribution of the population of this study, comparisons between racial groups cannot be made with validity. The final limitation of the study is that students were not asked questions about reading on handheld devices such as cell phones, this limitation has been remedied in the next generation of this study.

\section{Summary and Future Research}

Students in this study were found to own computers, have home internet access, use the internet to gather news and information, and be comfortable reading off a computer screen; however, few had experiences with e-books. While a small number of students said that they would purchase an e-book over a traditional textbook if given the option, the majority of the respondents reported that they prefer paper-based books to e-books. The low number of participants who said that they regularly read online newspapers and magazines further enforced this. These findings suggest that at this time e-books may be a hard sell in higher education, in particular at minority serving institutions. 
This research study has been expanded. More in-depth questions regarding cell phone and handheld usage are being introduced and an experimental model has been created to test the impact of format, e.g. hardcopy, via computer screen, and over a handheld, on reading comprehension and overall satisfaction.

\section{References}

Abbott, W. \& Kelly, K. (2004). Sooner or later! Have e-books turned the page? Library Papers. Posted through ePublications@Bond University. Retrieved from https://epublications.bond.au/library-pubs/5

AlShaali, S. \& Varshney, U. (2005) On the usability of mobile commerce. International Journal of Mobile Communications, 3(1), 29-37.

Berglund, Y., Morrison, A., Wilson, R. \& Wynne, M. (2004). An investigation into free ebooks. AHDS Final Report.

Brown, M. C. (2004). African-American student achievement in historically black colleges and universities. Diversity Digest, 8(1), 6-7.

Buzzetto-More, N. \& Sweat-Guy, R. (2007). The technology ownership and information acquisition habits of HBCU freshmen. Interdisciplinary Journal of Information, Knowledge, and Management, 2(1), 5972. Retrieved 1/21/07 from http://ijikm.org/Volume2/IJIKMv2p059-072Buzzetto252.pdf

Buzzetto-More, N., Sweat-Guy, R., \& Jewell, C. (2006). Technology backgrounds at freshmen students at two historically black universities. Global Digital Business Review, 2.

Cohen, E. \& Nycz, M. (2006). Learning objects e-learning: An informing science perspective. Interdisciplinary Journal of Knowledge and Learning Objects, 2, 23-24. Retrieved from http://ijklo.org/Volume2/v2p023-034Cohen32.pdf

de Salas, K. \& Ellis, L. (2006). The development and implementation of learning. Interdisciplinary Journal of Knowledge and Learning Objects, 2, 1-22. Retrieved from http://ijklo.org/Volume2/v2p001022deSalas.pdf

Dillon, A. (1992) Reading from paper versus screens: A critical review of the empirical literature. Ergonomics, 35(10), 1297-1326.

Downes, S. (2007). Models for sustainable open educational resources. Interdisciplinary Journal of Knowledge and Learning Objects, 3, 29-44. Retrieved from http://ijklo.org/Volume3/IJKLOv3p029044Downes.pdf

Dyson, M., \& Haselgrove, M. (2000). The effects of reading speed and reading patterns on the understanding of text read from screen. Journal of Research in Reading, 23(2), 210-223.

Fox, M. (2003). A library in your palm. Library Journal, 128(7), 10-13.

Gallenseon, A., Heins, J. \& Heins, T. (2002). Macromedia MX: Creating learning objects. [Macromedia White Paper]. Macromedia Inc. Retrieved from http://download.macromedia.com/pub/elearning/objects/mx_creating_lo.pdf

Johnson, C., \& Harroff, W. (2006). The new art of making books. Library Journal, 131(11), 8-12.

Mash, S.D. (2003). Libraries, books, and academic freedom. Academe, 89(3), 50-55.

Mattison, D. (2002). Alice in e-book land: A primer for librarians. Computers in Libraries, 22(9), 14-21.

Moore, D., \& Zabrucky, K. (1995). Adult age differences in comprehension and memory for computerdisplayed and printed text. Educational Gerontology, 21, 139-150.

National Endowment for the Arts. (2004). Reading at risk: A survey of literary reading in America. Retrieved 3/16/07 from www.arts.gov

Peters, T. (2000). Academic Libraries Take an E-Look at Ebooks. Retrieved online 1/13/07 from http://www.geocities.com/lbell927/ 
Poon, L., \& Meyer, B. (1997). Age differences in efficiency of reading comprehension from printed versus computer displayed text. Educational Gerontology, 23(8), 789-807.

Prensky, M. (2001). Digital natives, digital immigrants. On the Horizon, 9(5), 1-5.

Recker, M., Dorward, J., Dawson, D., Halioris, S., Liu, Y., Mao, X., Palmer, B. \& J. Park (2005). You can lead a horse to water: Teacher development and use of digital library resources. Proceedings of the Fifth ACM/IEEE Joint Conference on Digital Libraries, June 7 - 11, Denver, CO, 1-8.

Rogers, M. (2001). Survey reveals college students' growing preference for e’texts. Library Journal, 126 (2), 31 .

Rogers, M. (2006). Ebooks struggling to find a niche. Library Journal, 131(11), 25-26.

Rogers, M., \& Roncevic, M. (2002). E-book aftermath: Three more publishers fold electronic imprints. Library Journal, 127(1), 4.

Salaway, G., Katz, R. N., \& Caruso, J. B. (2006). The ECAR study of undergraduate student and information technology. Educause Quarterly, 29(4), 1-12.

Shirattudin, N., Hassan, S., \& Landoni, M. (2003). A usability study for promoting eContent in higher education. Educational Technology \& Society, 6(4), 112-124.

Striphas, T. (2006). Disowning commodities: Ebooks, capitalism, and intellectual property law. Television and New Media, 7(3), 231-260.

Weeks, L. (2002, July 6). Ebooks not exactly flying off the shelves: Most readers stick to paper despite technology's hype. The Washington Post.

Wicht, H. (2006). Buying e-books. Library Journal, 131(11), 15-17.

Wilson, R. (2003). Ebook readers in higher education. Education Technology and Society, 6(4), 8-17.

\section{Biographies}

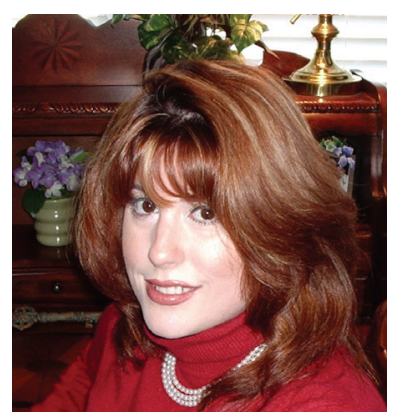

Dr. Nicole A. Buzzetto-More is an Assistant Professor, Business Education program coordinator, and Assurance of Learning coordinator in the Department of Business, Management, and Accounting at the University of Maryland Eastern Shore. She is also Co-Founder of the UMES Office of Instructional Technology. She received doctorate and masters degrees in communication and instructional technology from Columbia University and also holds degrees from the College of New Rochelle and Marist College. As a recognized assessment and elearning expert, she is a frequent presenter at conferences across the globe. She is on the editorial board of several journals, has authored numerous publications in referred journals, and has been recognized with an award from the American Distance Education Consortium. Her two books published in early 2007, Principles of Effective Online Teaching and Advanced Principles of Effective E-Learning, are available through the Informing Science Press. She is currently working on her third book.

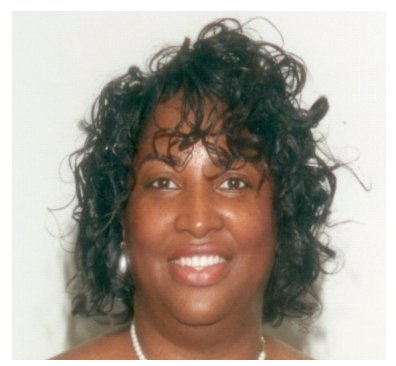

Dr. Retta Sweat-Guy has an Ed.D. in Curriculum and Instruction with emphasis in Instructional Systems Design from the University of Kentucky. She received her masters in Public Administration from Kentucky State University and a Bachelor of Arts degree in Business Education from the University of Kentucky. Currently, she is Assistant Professor in the Department of Marketing and Business Education at Fayetteville State University in Fayetteville, North Carolina. Online 
teaching and learning serves as the basis for her current research for which she has presented at conferences and referred publications. She has and continues to conduct workshops and training sessions on the uses of web-based course management tools. She has published several book chapters and is currently working on her first fully authored book.

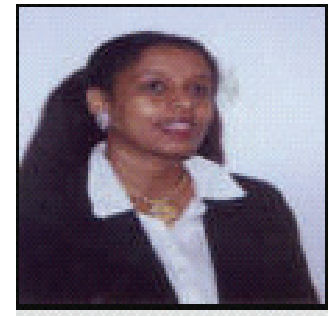

Ms. Muna Elobaid earned a masters degree in Computer Science from the University of Maryland Eastern Shore where she currently serves as a Lecturer in the Department of Business, Management and Accounting. Her research interests include distance learning, computer applications and/or technology as well as computer science and information systems. 